\title{
Detection of Milk Clotting Enzyme Produced by Lactic Acid Bacteria Isolated from Fermented Food
}

\author{
Mohamed Muftah Ahmad ${ }^{1 *}$ and Zaiton Hassan ${ }^{2}$
}

\begin{abstract}
Lactic acid bacteria (LAB) are known to produce extracellular enzymes that could be exploited for use in the dairy industry. Two LABs isolated from fermented foods (paste shrimp) were evaluated for extracellular proteinase production, milk clotting activity (MCA) and proteolytic activity (PA). The two isolates were identified by (API 50CHL) as Pediococcus acidilactici SH, and Lactobacillus paracasei CF1. These LABs showed proteolytic activity using skim milk agar as indicated by the visible clear zones developed in skim milk agar. $P$. acidilactici $\mathrm{SH}$ showed high MCA $50 \mathrm{SU} / \mathrm{ml}$ with PA $1.9 \mathrm{U} / \mathrm{ml}$ while $L$. paracasei CF1 showed MCA $44 \mathrm{SU} / \mathrm{ml}$ ) with PA $3.5 \mathrm{U} / \mathrm{ml}$ using trypticase peptone as a nitrogen source in enzyme production media. MCA was not observed when the LABs were grown in MRS broth. This study indicates the possibility of exploiting LAB from food sources for the production of milk-clotting enzymes for dairy production.
\end{abstract}

Keywords: Lactic acid bacteria, Lactobacillus paracasei, Pediococcus acidilactici, Milk clotting enzyme, Proteolytic activity.

\section{INTRODUCTION}

Lactic acid bacteria play important role in the production of fermented food products, such as yogurt and cheeses. These include biochemical events taking place during milk clotting in cheese processing and during ripening. LABs are also known to produce extracellular proteinaces and LABs such as $L$. helveticus (Hebert et al., 2001), L. paracasie) (Ikram et al., 2006) and Enterococcus faecalis 2495L, E. faecalis IAM10065 and E. faecalis 156 (Sato et al. (2004) were reported to have enzymes with milk clotting activity (MCA). Most microbial sources of milk clotting enzymes (MCE) are from fungi such as Aspergllus niger et al., 2010) and Rhizomucor Miehei (Merheb, et al., 2010), but the MCE from fungi showed high proteolysis which leads to a weak body, bitter flavor defects and reduced cheese yield during storage (Yegin, et al., 2010; Moosavi-Nasab et al, 2010). Increased demand for dairy product, low availability of rennet which comes from calves has led to the replacement of calf rennin by microbial milk clotting enzymes (Kurutahalli et al. 2010). Therefore, the purpose of this study was to detect the milk clotting activity (MCA) of LAB isolated from fermented foods that could offer possible source of enzyme that could result in clotting of casein in milk.

\section{MATERIALS AND METHODS}

Isolation and Identification of lactic acid bacteria

Lactic acid bacteria were isolated from different sources of fermented food (such as fermented paste shrimp, fermented cocoa, fermented buffalo milk, and yoghurt also from different fruit obtained from local markets and soil). A total of $10 \mathrm{~g}$ of sample was homogenized in peptone water (Oxoid) using stomacher (Stomacher R 400 Circular Seward) for $2 \mathrm{~min}$. For fermented fish (Pekasam) and fermented shrimp (Belacan) samples were diluted in $6.5 \%(\mathrm{w} / \mathrm{v}) \mathrm{NaCl}$. The samples were appropriately diluted and spread plated on modified MRS agar (De Man-Rogosa). The plates were incubated anaerobically at $37^{\circ} \mathrm{C}$ for $48 \mathrm{~h}$. .(Aween et. Al 2012).

\section{Identification of LAB API 50 CHL strips}

The API 50 CHL strips (API systems, Biomerieux, France) consisting of 50 microtubes were used to identify the LAB isolates based on carbohydrate fermentation profile. Overnight bacteria cultures were incubated according to the manufacturer's instructions and the bacterial suspension was prepared with the turbidity equivalent to McFarland 2 standard. The strips of the API $50 \mathrm{CHL}$ test were filled with the inoculated API suspension and overlaid with mineral oil. The inoculated strips were incubated at $37^{\circ} \mathrm{C}$ and the reactions were observed after 24 and $48 \mathrm{~h}$ of incubations. The results were analyzed by API software version (BioMerieux).

Detection and screening of LAB for the production of extracellular proteinase

The production of extracellular proteinase was detected following the method described by (Imdakim et al 2015) with some modification as follows: $25 \mathrm{~g}$ of skim milk was reconstituted with $250 \mathrm{ml}$ of distilled

\footnotetext{
DOI: 10.21608/asejaiqjsae.2019.46830

${ }^{1}$ Faculty of Agriculture sebha University, Libya.

${ }^{2}$ Faculty of Science and Technology, Universiti Sains Islam Malaysia (USIM)

71800, Bandar Baru Nilai, Negeri Sembilan, Malaysia

*Corresponding author: Emdakim1@yahoo.com

Received July 24, 2019, Accepted August 26, 2019
} 
water, stirred thoroughly and autoclaved at $110{ }^{\circ} \mathrm{C}$ for $10 \mathrm{~min}$. $500 \mathrm{ml}$ of $2.5 \%$ agar No3 (Oxoid) was sterilized at $121{ }^{\circ} \mathrm{C}$ for $20 \mathrm{~min}$, then mixed with skim milk and poured into a plated petri dish Lactic acid bacteria was spot inoculated on prepared skim milk agar media then incubated at $37^{\circ} \mathrm{C}$ for $48 \mathrm{~h}$ in an anaerobic jar followed by cooling room at $4{ }^{\circ} \mathrm{C}$ for 3 days. Protein digestion was observed by the clear zones surrounding the colonies. LAB that produced good extracellular proteinase activity was sub-cultured in MRS agar incubated at $37^{\circ} \mathrm{C}$ for $24 \mathrm{~h}$, anaerobically. Each strain was inoculated into a test tube containing $5 \mathrm{ml}$ of skim milk $(10 \%) \mathrm{w} / \mathrm{v}$ and cultivated statically at $30{ }^{\circ} \mathrm{C}$ for 7 days. Strains which formed good clot of casein with clear and little whey were selected for further study.

\section{Media Preparation for MCE production}

The enzyme production media consisted of trypticase peptone $(10 \mathrm{~g})$, glucose $\left(\begin{array}{ll}10 & \mathrm{~g}\end{array}\right)$, $\mathrm{CH}_{3} \mathrm{COONa} \cdot 3 \mathrm{H}_{2} \mathrm{O}(2 \mathrm{~g}), \quad \mathrm{MgSO}_{4} \cdot 7 \mathrm{H}_{2} \mathrm{O}(200 \mathrm{mg})$, $\mathrm{MnSO} \bullet 4 \mathrm{H}_{2} \mathrm{O}(10 \mathrm{mg}), \mathrm{FeSO}_{4} \bullet 7 \mathrm{H} 2 \mathrm{O}(10 \mathrm{mg}), \mathrm{NaCl}(10$ $\mathrm{mg}$ ) dissolved in D.W. $1000 \mathrm{ml}$ and adjusted to $\mathrm{pH}$ of 6.8 with $\mathrm{NaOH}$ was used. One $\mathrm{ml}$ of the $24 \mathrm{~h}$ precultured broth was inoculated into Erlenmeyer flask containing $100 \mathrm{ml}$ of the enzyme production medium without or with $1 \% \mathrm{CaCO}_{3}$ sterilized by autoclaved at $121{ }^{\circ} \mathrm{C}$ for $15 \mathrm{~min}$. The enzyme production media with $\mathrm{CaCO}_{3}$ was incubated in a shaker incubator $(150 \mathrm{rpm})$ at $30{ }^{\circ} \mathrm{C}$ for $48 \mathrm{~h}$, followed by centrifuged at $9,000 \mathrm{x}$ g for $20 \mathrm{~min}$ at $4{ }^{\circ} \mathrm{C}$. The supernatant was collected and filtered using $0.22 \mu \mathrm{m}$ regenerated cellulose membrane filter before analysis of MCA and proteolytic activity (PA), and determination of the MCA/ PA ratio (Sato et al., 2004).

\section{The MCE assay}

Enzyme assay was carried out following the method described by Sato et al. (2004). Skim milk (10\%w/v, Oxoid) containing $10 \mathrm{mM}$ of $\mathrm{CaCl}_{2}$ was used as substrate, pre-incubated at $40{ }^{\circ} \mathrm{C}$ for $5 \mathrm{~min} . \quad 0.5 \mathrm{ml}$ of the enzyme extract was added to $5 \mathrm{ml}$ of substrate solution, mixed well and incubated at $35^{\circ} \mathrm{C}$. The time $T$ (s), taken from the addition of the enzyme to the first appearance of clots of milk solution was recorded. MCA was calculated using the following formula: $\mathrm{SU}=$ 2400/T $\times S / E$ whereas,

$T=$ clotting time (s), $S=$ substrate solution $(\mathrm{ml}), E=$ enzyme solution ( $\mathrm{ml}$ )

\section{Determine the PA of enzyme from LAB}

The method described by Sato et al. (2004) was used to determine the proteolytic activity of the cell free enzyme production media. Hammerstein casein $1 \%$ was dissolved in $0.1 \mathrm{M}$ Tris - Hcl buffer $\mathrm{pH} 7.5$ as substrate, and $5 \mathrm{ml}$ of this substrate solution was incubated with
$1 \mathrm{ml}$ of crude enzyme solution at $45^{\circ} \mathrm{C}$ for $30 \mathrm{~min}$; then the enzyme reaction was stopped with $5 \mathrm{ml}$ of trichloroacetic acid mixture $\left(0.11 \mathrm{M} \mathrm{CCl}_{3} \mathrm{COOH}, 0.22\right.$ $\mathrm{M} \mathrm{CH}_{3} \mathrm{COONa}$ and $0.33 \mathrm{M} \mathrm{CH} 3 \mathrm{COOH}$ ). After incubation for $30 \mathrm{~min}$ the mixture was filtered using Whatman filter paper No.1, and $2 \mathrm{ml}$ of the filtrate was added to $5 \mathrm{ml}$ of $0.55 \mathrm{M} \mathrm{Na}_{2} \mathrm{CO}_{3}$ and $1 \mathrm{ml}$ of Folin's reagent (diluted 1:3). The reaction mixture was held at $30^{\circ} \mathrm{C}$ for $30 \mathrm{~min}$ and the optical density at $660 \mathrm{~nm}$ was measured using UV-Visible Spectrophotometer (4001/4, Thermo Spectronic, USA). One unit of proteolytic activity is defined as the amount of enzyme which released $1 \mu \mathrm{g}$ of amino acid expressed as the tyrosine concentration per min under the above condition. The change in absorbance in test samples was determined by calculating the difference between test samples absorbance and absorbance of test blank. Inserting the absorbance value for one of the test samples into the slope equation, micromoles of tyrosine liberated during the proteolytic reaction was determined as follows.

Units/ml enzyme $=($ mole tyrosine equivalents released $) x(V 1)$

$$
\text { (V2) (T) (V3) }
$$

Where:-

$V 1=$ total volume (in $\mathrm{ml}$ ) of assay

$T=$ time of assay in min as per the unit defined

$V 2=$ volume of enzyme (in $\mathrm{ml}$ ) used

$V 3=$ volume (in $\mathrm{ml}$ ) used in colorimetric determination

\section{RESULTS AND DISCUSSION}

\section{Isolation and identification of $\mathrm{LAB}$}

The LAB were gram positive and catalase negative rods or cocci and identified as Pediococcus acidilactici and Lactobacillus paracasei (Table 1).

Table 1. Identification of LAB isolates by API 50 CHL

\begin{tabular}{clcc}
\hline Code & \multicolumn{1}{c}{ API CH50 } & \%ID & T \\
\hline SH & Pediococcus acdilactici & 99.9 & 0.80 \\
CF1 & Lactobacillus lactis cremoris & 93.7 & 0.66 \\
\hline
\end{tabular}

Detection and Screening of LAB for the production extracellular proteinase

The two LAB isolates produced extracellular proteinase was assayed using skim milk agar plate and expressed as the clear zone surrounded the colonies (Fig. 1) The activity of protein degradation was indicated by clear zone surrounding the colony (Aween el at., 2012). The coagulated casein was large, soft, white color with very little amount of whey (Fig.2) These observations indicates that the enzymes produced by the two LAB could clot skim milk protein. 


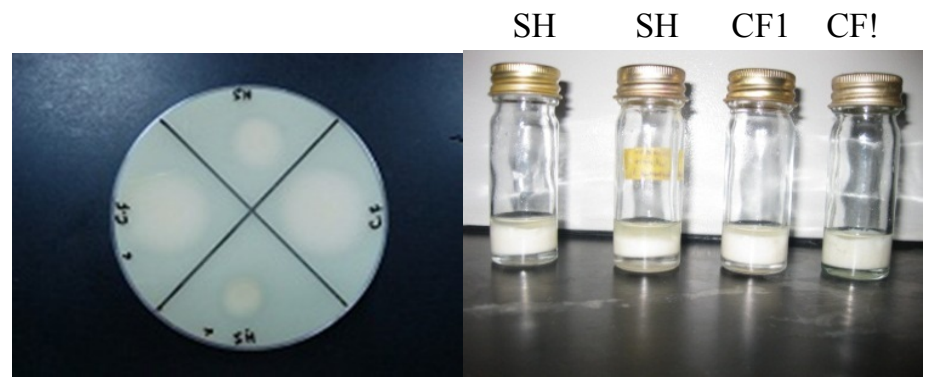

Fig. 1. Extracellular proteinase activity of SH

Fig.2. Milk Clotting activity of CF1 and SH

Fig.1, 2, 3 Detection and screening of LAB for producing extracellular proteinase

Table 2. MCA, PA of crude enzyme of LAB isolated from different sources

\begin{tabular}{cccccc}
\hline $\begin{array}{c}\text { Isolates } \\
\text { Code }\end{array}$ & $\begin{array}{c}\text { Clotting } \\
\text { time(s) }\end{array}$ & $\begin{array}{c}\text { MCA } \\
\text { (SU } \backslash \mathbf{m l})\end{array}$ & PA(u\ml) & R \\
\hline C.F1 & 82 & 44 & 3.5 & 12.8 \\
SH & 72 & 50 & 1.9 & 26.3 \\
\hline
\end{tabular}

$R=M C A \mid P A$

\section{The MCA and PA assay}

Table 2 shows the results of MCA and PA of crude enzyme from LAB isolates. P. acdilactici $\mathrm{SH}$ produced the highest amount of MCA $(50 \mathrm{SU} / \mathrm{ml})$ and lowest PA $(1.9 \mathrm{U} / \mathrm{ml})$, while $L$ paracasei $\mathrm{CF} 1$ isolate produced the lowest amount MCA (44 SU/ml) and highest PA (3.5 $\mathrm{U} / \mathrm{ml}$ ). High proteolytic activity normally leads to lower yield, soft body and bitter taste of milk curd. The ration of MCA/PA for crude enzyme of $P$. acdilactici $\mathrm{SH}$ was high (26.3) compared to L. paracasei CF1 (12.8) (Table. 2). The ratio of MCA to PA is used as an indicator for selecting the potential strain to clot milk casein. The ability to produce extracellular proteinases is one of the important features of LAB in making cheese. Most of LAB isolated from fermented products have multiple amino acid auxotrophy and in order for LAB to grow in protein rich media such as milk, they depend on the expression of a complex proteolytic system for the degradation of protein. In addition, proteinases play significant role in the formation of gel texture of protein due to protein degradation.

The results obtained in this study showed that the enzyme produced by $P$. acidilactici $\mathrm{SH}$ isolated from Malaysian fermented foods can be used as clotting enzyme for the manufacture of dairy products.

\section{ACKNOWLEDGEMENT}

The authors wished to express their gratitude to the management of the Faculty of Science and Technology, Universiti Sains Islam Malaysia (USIM), Bandar Baru Nilai for supporting this novel work.

\section{REFERENCE}

Aween MM, Hassan Z, Muhialdin BJ, Noor HM, Eljamel YA (2012). Evaluation on antibacterial activity of Lactobacillus acidophilus strains isolated from honey. Am. J. Appl. Sci. 6:807-817.

Hebert EM, De Giori GS, Raya RR (2001). Isolation and Characterization of a Slowly Milk-Coagulating Variant of Lactobacillus helveticus. Appl. Env. Microb. 67:18461850.

Kurutahalli S. Vishwanatha, Appu Rao A.G., Singh S.A., 2010. Production and characterization of a milk-clotting enzyme from Aspergillus oryzae MTCC 5341. Appl. Microbiol. Biotechnol. 85, 1849-1859.

Merheb-Dini C, Gomes E, Boscolo M, da Silva R (2010). Production and characterization of a milk-clotting protease in the crude enzymatic extract from the newly isolated Thermomucor indicae-seudaticae N31: (Milkclotting protease from the newly isolated Thermomucor indicae-seudaticae N31). Food Chemistry Vol. 120:8793. 
Moosavi-Nasab M, Radi M, Jouybari HA (2010). Investigation of enzyme modified cheese production by two species of Aspergillus. Afri J Biotech, 9: 508-511.

Sato S, Tokuda H, Koizumi T, Nakanishi K (2004). Purification and Characterization of an Extracellular Proteinase Having Milk-Clotting Activity from Enterococcus faecalis TUA2495L. Food Sci. Tech. Res. $10: 44-50$.
Yegin S, Fernández-Lahore $\mathrm{M}$, Guvenc U, Goksungur $\mathrm{Y}$ (2010). Production of extracellular aspartic protease in submerged fermentation with Mucor mucedo DSM 809. Afr. J. Biotech.. 38:6380-6386. 